\title{
The Eukaryotic Tree of Life from a Global Phylogenomic Perspective
}

\author{
Fabien Burki \\ Canadian Institute for Advanced Research, Department of Botany, University of British Columbia, \\ Vancouver, British Columbia V6T 1Z4, Canada \\ Correspondence: burkif@mail.ubc.ca
}

\begin{abstract}
Molecular phylogenetics has revolutionized our knowledge of the eukaryotic tree of life. With the advent of genomics, a new discipline of phylogenetics has emerged: phylogenomics. This method uses large alignments of tens to hundreds of genes to reconstruct evolutionary histories. This approach has led to the resolution of ancient and contentious relationships, notably between the building blocks of the tree (the supergroups), and allowed to place in the tree enigmatic yet important protist lineages for understanding eukaryote evolution. Here, I discuss the pros and cons of phylogenomics and review the eukaryotic supergroups in light of earlier work that laid the foundation for the current view of the tree, including the position of the root. I conclude by presenting a picture of eukaryote evolution, summarizing the most recent progress in assembling the global tree.
\end{abstract}

It is redundant to say that eukaryotes are diverse. Plants, animals, and fungi are the charismatic representatives of the eukaryotic domain of life, but this narrow view does not do justice to the eukaryotic diversity. Microscopic eukaryotes, often unicellular and known as the protists, represent the bulk of most major groups, whereas multicellular lineages are confined to small corners on the global tree of eukaryotes. If all eukaryotes possess structures enclosed within intracellular membranes (the organelles), an infinite variation of forms and feeding strategies has evolved since their origin. Eukaryotic cells can wander on their own, sometimes forming hordes of free-living pico-sized organisms that flourish in oceans. They can be parasites or symbionts, or come together by the billions in tightly packed, highly regulated mul- ticellular organisms. Eukaryotes have occupied just about every ecological niche on Earth. Some actively gather food from the environment, others use plastids (chloroplasts) to derive energy from the light; many can adapt to variable conditions by switching between autotrophy and the predatory consumption of prey by phagotrophy. Eukaryotes also show a great deal of genomic variation (Lynch and Conery 2003). Some amoebozoan protists, for instance, have the largest known genomes-more than 200 times larger than that of humans (Keeling and Slamovits 2005). Conversely, microbial parasites can have highly compact, bacterialsize genomes (Corradi et al. 2010). Even smaller are the remnant nuclear genomes (nucleomorphs) of what were once free-living microbial algae. At around 500,000 nucleotides and

Editors: Patrick J. Keeling and Eugene V. Koonin

Additional Perspectives on The Origin and Evolution of Eukaryotes available at www.cshperspectives.org

Copyright (C) 2014 Cold Spring Harbor Laboratory Press; all rights reserved; doi: 10.1101/cshperspect.a016147

Cite this article as Cold Spring Harb Perspect Biol 2014;6:a016147 
hardly encoding a few hundreds genes, nucleomorphs are the smallest nuclear genome of all (Douglas et al. 2001; Gilson et al. 2006; Lane et al. 2007).

Recognizing this great diversity and pushed by a desire to establish order, biologists have long attempted to assemble a global eukaryotic tree of life. A fully resolved phylogenetic tree including all organisms is not only the ultimate goal of systematics, it would also provide the foundation to infer the acquisition and evolution of countless characters through the history of long-dead species. But early attempts to resolve the eukaryotic tree, most of which were based on comparisons of morphology and nutrition modes, faced the impossible challenge of describing in an evolutionary sensitive way a world in which most of the diversity occurs among tiny microbes. For decades, biology textbooks assigned the eukaryotes to evolutionary entities called "kingdoms" in which the lords were the animals, plants, and fungi (Copeland 1938; Whittaker 1969; Margulis 1971). This is not to say that biologist ignored protists, and they have been in fact recognized as a kingdom for more that a century (Haeckel 1866), but protists were considered to be "simple" organisms from which more elaborate, multicellular species emerged. Although these early proposals succeeded in recognizing several major assemblages, such as animals and plants, they were less successful in resolving the relationships between the groups and, with the benefit of hindsight, failed to account for the fundamental paraphyletic and complex nature of the protist lines.

\section{A MOLECULAR (R)EVOLUTION}

The backbone of the eukaryotic tree has gone through some profound rearrangements in the past 20 years. Comparing nucleotide or amino acid sequences is now the tool of choice for reconstructing evolutionary histories. This is particularly true for protists because the interpretation of their morphological characters alone is problematic. For years, the go-to molecular marker for phylogenetics has been the small subunit ribosomal RNA (SSU rRNA). It is easy to amplify and contains both hypervariable and conserved regions, allowing researchers to investigate different depths of phylogenetic resolution. As a result, the SSU rRNA dominates molecular databases, and the majority of the known eukaryotic diversity, when characterized molecularly, is still defined solely by this marker.

The pioneering molecular phylogenies consistently recovered a handful of deeply diverging protist lineages (e.g., diplomonads, parabasalids, microsporidians, Archamoebae), progressively emerging from the distant prokaryotic root, and followed by a densely branched "crown," nesting the more familiar eukaryotic diversity (Sogin et al. 1986, 1989; Friedman et al. 1987; Woese et al. 1990; Sogin 1991). This was an appealing picture of evolution because these early diverging species were seemingly morphologically simple single-cell organisms that lacked mitochondria and other typical eukaryotic structures, such as peroxisomes (Keeling 1998). These phylogenies were also consistent with the archezoa hypothesis, which postulated that amitochondriate eukaryote lineages diverged before the endosymbiotic event that gave rise to mitochondria (CavalierSmith 1983, 1987, 1989). Even more convincing was that other molecular markers, including various elongations factors and RNA polymerase subunits, corroborated the deep-branching position of archezoan taxa, altogether supporting the prediction that they should branch earlier than the mitochondrion-containing eukaryotes if they predate the origin of this organelle (Brown and Doolittle 1995; Klenk et al. 1995; Kamaishi et al. 1996; Yamamoto et al. 1997).

At the other end of the tree, the so-called crown, contain the major clades of eukaryotes, appearing tightly bunched together as if they diverged almost simultaneously (Sogin 1991; Knoll 1992). These clades included animals, fungi, and plants as well as diverse protist lineages such as alveolates and stramenopiles (see below). The branching pattern among the SSU rRNA crown taxa, however, could not be resolved even with the help of several protein markers (Baldauf 1999; Hirt et al. 1999; Roger 
et al. 1999; Moreira et al. 2000). This lack of molecular resolution was interpreted as evidence that not enough phylogenetic signal could accumulate in the sequences because most phyla emerged in a very short period of time, like in a "big-bang" explosion of species diversification (Philippe et al. 2000a,b).

\section{TRIMMING THE TREE}

The early molecular-based interpretation of the eukaryotic tree showing the archezoancrown dichotomy did not last very long. First, as more and more lineages were being sequenced, mitochondriate protist groups such as Euglenozoa and Foraminifera squeezed in between the archezoan taxa and the crown (Sogin et al. 1986; Clark and Cross 1988; Pawlowski et al. 1996). Moreover, the archezoans were characterized by elevated rates of molecular evolution, which translates into long branches in phylogenetic trees (Philippe et al. 2000b). This meant that for these "basal" taxa, most standard molecular markers such as the SSU rRNA were mutationally saturated, a feature that can lead to the notorious long branch attraction (LBA) artefact in which distantly related species with fast evolving sequences are erroneously clustered together (Felsenstein 1981). Ultimately, new genes, more taxa, and better phylogenetic methods showed that if the archezoan taxa appeared to diverge early, it was not because they were "primitive" eukaryotes but rather because of their artificial attraction to the base of the tree by distant outgroups (Embley and Hirt 1998; Roger 1999; Baldauf et al. 2000; Philippe et al. $2000 \mathrm{a}, \mathrm{b})$. At the same time, mitochondrial-derived genes were progressively discovered in archezoan genomes, the products of which were shown to be targeted to reduced double-membrane-bounded organelles of mitochondrial ancestry (hydrogenosomes and mitosomes), suggesting that all "amitochondriate" eukaryotes once possessed mitochondria (Clark and Roger 1995; Bui et al. 1996; Keeling 1998; Tovar et al. 1999, 2003; Williams et al. 2002; Embley and Martin 2006; Goldberg et al. 2008; Hjort et al. 2010). This marked the end of both the archezoa hypothesis and the concept of a eu- karyotic crown, and no longer supported the idea that the prokaryote-to-eukaryote transition was a progressive transformation involving intermediate amitochondriate forms.

More generally, the whole eukaryotic tree was shaken up by important discrepancies between SSU rRNA-based phylogenies and those inferred from a growing number of proteincoding genes, as well as discrete molecular characters such as shared indels (insertion/deletions) or gene fusions, or the systematic analysis of light and electron microscopy data (e.g., Baldauf and Palmer 1993; Keeling and Doolittle 1996; Fast et al. 1999; Baldauf et al. 2000; Moreira et al. 2000; Cavalier-Smith 2002; Simpson 2003; Nikolaev et al. 2004; Harper et al. 2005). The integration of these various kinds of data led to the conception that most, if not all, eukaryotic diversity can be assigned to one of several major assemblages, called "supergroups" (Baldauf 2003; Keeling 2004; Simpson and Roger 2004; Adl et al. 2005; Keeling et al. 2005; Parfrey et al. 2006). In this framework, animals occupy just one branch among hundreds, and are far outnumbered at the level of major lineages by unicellular eukaryotes. In its original form, this new tree of eukaryotes was an unrooted polytomy with six main stems, each representing a supergroup: Opisthokonta, Amoebozoa, Excavata, Archaeplastida, Rhizaria and Chromalveolata. All six of these supergroups emerged from a common point, and their order of divergence was mostly unknown.

\section{PHYLOGENETICS + GENOMICS = PHYLOGENOMICS}

Fast forward to present day, we are well into the genomic era and reconstructing the tree of eukaryotes is no longer the job of a few genes. Instead, huge phylogenomic data sets containing hundreds of genes for an always-increasing number of taxa can now be used. The tedious and expensive Sanger sequencing of the early 2000s (the human genome cost in the range of a billion U.S. dollars) has been replaced by fast and cheap next-generation sequencing, which can produce genome-scale data at unprecedented depths for a taxonomically broad sampling. 


\section{F. Burki}

Once strongly biased toward organisms relevant for human well-being (of economical or medical importance), there has been an explosion of the taxonomic distribution of species for which extensive genomic data are available. As of 2012, at least one species from each major lineage of eukaryotes has had its genome fully sequenced, not to mention the numerous smaller scale genomic surveys and transcriptomic data sets that have been generated. With this wealth of sequence data at hand, phylogenomics started off as a way to predict gene functions by evolutionary analysis in which uncharacterized genes were predicted by their phylogenetic position relative to genes with known functions (Eisen 1998). Although this area of phylogenomics is still very active, it also rapidly emerged as a new domain of phylogenetics and became an essential tool for addressing controversial evolutionary questions, such as the transitions that led to the current diversity of eukaryotes.

In its most popular application to phylogeny, phylogenomics relies on multiple-sequence alignments, much like the single-gene approach, but here the genes are often concatenated into large supermatrices (Delsuc et al. 2005). With this approach, too, it is important to ensure the vertical transmission of the characters (orthology) — that the genes in related species are inherited from a common ancestor. This is not an easy task because the genes available from genomic-scale projects are still poorly sampled, substantially more so than for widely used phylogenetic protein markers such as actin, $\alpha$ - and $\beta$-tubulins, or translation elongation factor 2 . Consequently, differentiating between orthology and, for example, the undesirable horizontally transferred genes (HGTs), independent gene losses or partially sampled genes can be difficult to achieve with a limited taxon selection. Moreover, many of the general biases that apply to single-gene phylogenetics are exacerbated in a phylogenomic context (Jeffroy et al. 2006; Rodriguez-Ezpeleta et al. 2007b; Philippe et al. 2011). Phylogenetic reconstruction involves two opposing forces: the true phylogenetic signal carrying the evolutionary history, and the nonphylogenetic signals (noise) resulting from a combination of one or more causes such as saturated positions in the data set (stochastic errors) or model misspecifications (systematic errors). Stochastic errors arise when the number of positions in an alignment is small meaning that the random background noise, which inevitably accumulates through time because of homoplasy, will have a neutralizing effect on the positions that contain the genuine phylogenetic signal. Model misspecifications leading to systematic errors include, for example, the heterogeneity of nucleotide or amino acid composition, which tends to incorrectly cluster together species sharing the same composition, or the heterogeneity of the evolutionary rates, which can result in the LBA artefact (Felsenstein 1981; Philippe 2000; Lopez et al. 2002; Foster 2004; Ho and Jermiin 2004; Jermiin et al. 2004).

Logically, the goal of a phylogenetic inference is to minimize the noise and maximize the true phylogenetic signal (Philippe et al. 2005, 2011). Single-gene phylogenies, because of the limited information they contain, are especially susceptible to stochastic errors; to counter this, the obvious solution is to gather more data in the hope that enough phylogenetic signal is recovered (i.e., synapomorphy will dominate homoplasy). Systematic errors, on the other hand, tend not to vanish with the addition of more data as their causes do not average out over longer alignments (Rodriguez-Ezpeleta et al. 2007b). Yet, the key advantage of phylogenomics is precisely that more data is available to start with, making it possible to apply strategies to diminish the known sources of systematic errors while still maintaining most of the phylogenetic signal (see Delsuc et al. 2005; Philippe et al. 2005, 2011 for reviews). Thus, when combined with other options developed and tested on smaller data sets to increase the phylogenetic accuracy, such as the use of more accurate phylogenetic methods or better taxon samplings, phylogenomics becomes a very powerful tool.

Phylogenomics has confirmed the existence of most supergroups, although various degrees of controversy remain for each of them. The increased power in resolution has also led to some important shuffling among the super- 
groups and allowed the placement in the tree of several "orphan" lineages. Below, in the next section, I briefly introduce each supergroup, and discuss the eukaryote phylogeny in light of the most recent advances (see Fig. 1).

\section{THE EUKARYOTIC SUPERGROUPS}

\section{Opisthokonta}

This supergroup contains animals (Metazoa) and fungi, as well as several lines of heterotrophic protists. Animals emerged from within a paraphyletic assemblage of protists, including the choanoflagellates (e.g., Monosiga), Filasterea (e.g., Capsaspora), and Ichthyosporea (e.g., Sphaeroforma; Steenkamp et al. 2006; RuizTrillo et al. 2008; Shalchian-Tabrizi et al. 2008; del Campo and Ruiz-Trillo 2013). Fungi, including the monophyletic and early assemblage comprising Cryptomycota (e.g., Rozella), aphelids, and microsporidians (Lara et al. 2010; Jones et al. 2011a,b; James et al. 2013; Karpov et al. 2013) are closely related to nucleariid amoeba (Nuclearia simplex) and the aggregative slime mold Fonticula (Brown et al. 2009; Liu et al. 2009, 2012). Opisthokonts are putatively united by the presence of a single posterior flagellum in several representatives (CavalierSmith and Chao 1995), and many molecularbased evidences (single-gene phylogenies, phylogenomics, and indels) have consistently supported the existence of this group (e.g., Baldauf and Palmer 1993; Wainright et al. 1993; Baldauf et al. 2000; Brown et al. 2009; Liu et al. 2009). It is one of the most reliable supergroups.

\section{Amoebozoa}

This supergroup includes mostly amoeboid, heterotrophic protists such as the classical naked and testate lobose amoebae with broad pseudopods (e.g., Amoeba), but also contains some amitochondriate parasitic lineages of critical medical importance (e.g., Entamoeba), flagellated cells (e.g., Phalansterium, Multicilia), or the mycetozoan slime molds capable of aggregative multicellularity (e.g., Dictyostelium; see Pawlowski and Burki 2009 for a recent review). In addition to morphological similarities of the amoeboid cells, evidence that they form a monophyletic group is based on single-gene phylogenies (e.g., Fahrni et al. 2003; Smirnov et al. 2005), phylogenomics (Bapteste et al. 2002; Minge et al. 2009; Brown et al. 2012), and similarities in mitochondrial genome architecture between Acanthamoeba and Dictyostelium (Lonergan and Gray 1996; Iwamoto et al. 1998).

Opisthokonts and Amoebozoa are often united in a larger supergroup called the unikonts (Cavalier-Smith 2002) or, more recently, Amorphea (Adl et al. 2012), which is supported by a gene duplication/fusion (Stechmann and Cavalier-Smith 2002, 2003) as well as singlegene phylogenies (e.g., Baldauf and Palmer 1993) and phylogenomics (Rodriguez-Ezpeleta et al. 2007a; Hampl et al. 2009; Brown et al. 2012; Derelle and Lang 2012). Amorphea also contains protist lineages of unclear placement, such as the apusomonads, ancryomonads, and breviate amoebae. Based on phylogenomic analysis, opisthokonts, apusomonads, and breviates were recently grouped into a larger entity named Obazoa (Brown et al. 2013). The validity of this assemblage, however, relies on the position of the eukaryotic root, which remains hypothetical (see below).

\section{Excavata}

This supergroup is composed of diverse and mainly heterotrophic protists, many of which are anaerobes and/or parasites and possess hydrogenosomes or mitosomes instead of mitochondria (e.g., Giardia, Trichomonas). A group including lineages with plastids of green algal origin, the euglenids (e.g., Euglena), also belongs to this assemblage. Excavates were originally proposed based on a distinctive feeding groove supported by a particular set of cytoskeletal features that are found in some, but not all, of these organisms (Simpson 2003). A strong molecular confirmation of this grouping is currently lacking, which is at least, in part, attributable to the high rates of sequence evolution of most of its putative constituent lineages. Single-gene phylogenies (e.g., Kolisko et al. 2008; Takishita et al. 2012) and phylogenomics (Rodriguez-Ezpeleta 


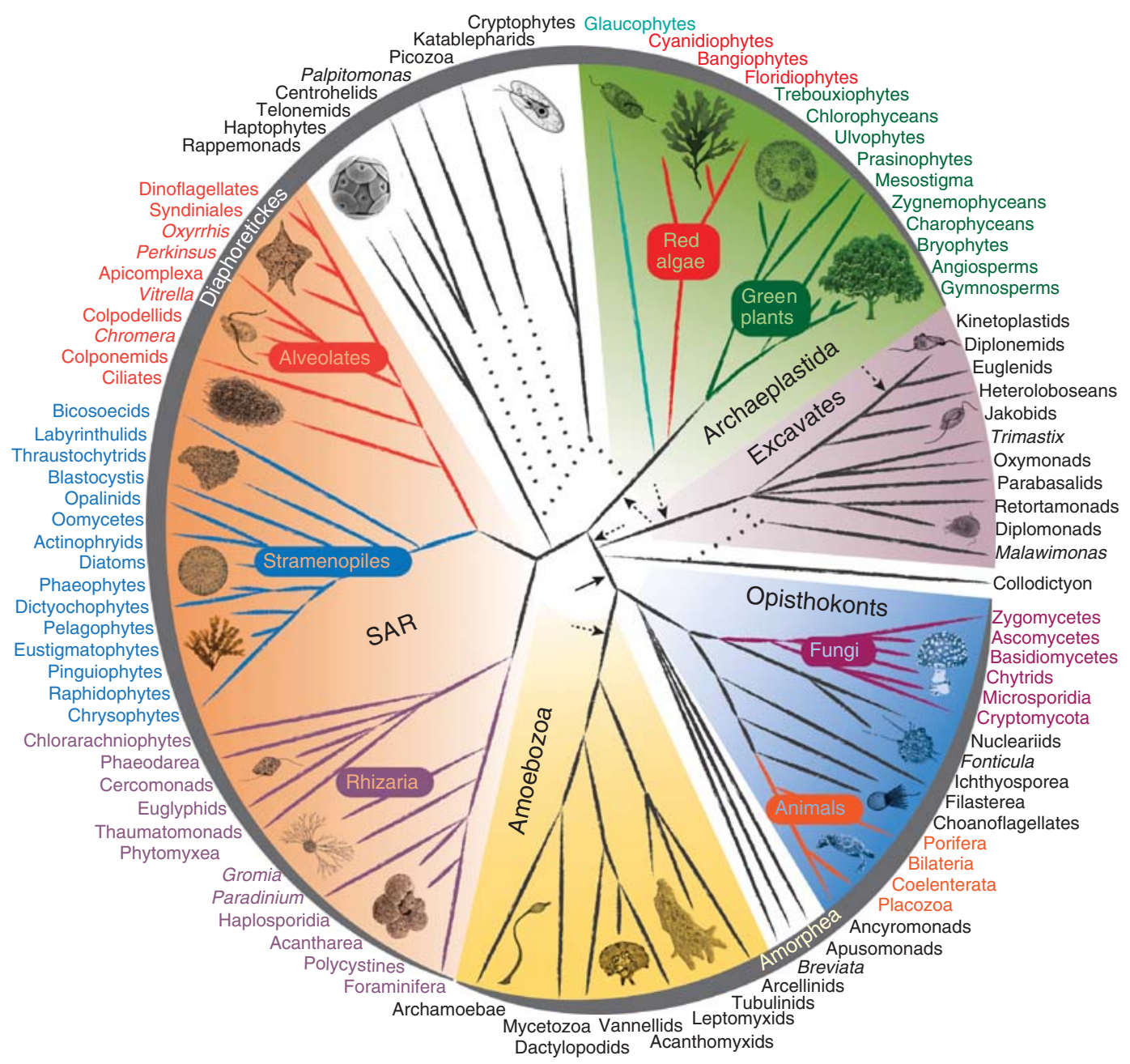

Figure 1. Global tree of eukaryotes from a consensus of phylogenetic evidence (in particular, phylogenomics), rare genomic signatures, and morphological characteristics. Numerous eukaryotic groups are shown (not exhaustively), regardless of their taxonomic rank. Cartoons illustrate the diversity constituting the largest assemblages (colored boxes). The branching pattern does not necessarily represent the inferred relationships between the lineages. Dotted lines denote uncertain relationships, including conflicting positions. Note the solid branch leading to haptophytes and rappemonads: This illustrates the strong support for placing haptophytes as sister to SAR(stramenopiles, alveolates, and Rhizaria) in a recent study (Burki et al. 2012b), but this lineage is not included in a colored assemblage because confirmation is needed. The arrows point to possible positions for the eukaryotic root; the solid arrow corresponds to the most popular hypothesis (Amorphea-bikont rooting), the broken arrows represent the alternative hypotheses discussed in the text. (This figure was inspired by a template provided by Y. Eglit.)

et al. 2007a; Hampl et al. 2009) have generally recovered the monophyly of the group when the fast-evolving taxa are excluded, but some lineages, such as Malawimonas, have eluded robust placement (Hampl et al. 2009; Zhao et al. 2012).

\section{Archaeplastida (Plantae)}

This supergroup is composed of the three main lineages of primary photosynthetic taxa: organisms that harbor plastids directly derived from the cyanobacterial endosymbiosis. (1) The glau- 
cophytes (e.g., Cyanophora) are a small group of enigmatic freshwater microscopic algae with uniquely cyanobacterial-like plastids (they have retained the prokaryotic peptidoglycan layer between the two plastid membranes). (2) The red algae (rhodophytes) form a diverse group of unicellular algae and large seaweeds, for example, the genus Porphyra commonly used to wrap sushi (nori). (3) The "green" organisms (Viridiplantae), including the green algae, with mostly free-living unicellular (e.g., Chlamydomonas) and colonial or multicellular taxa (e.g., Volvox, Caulerpa), but nonphotosynthetic parasitic taxa (e.g., Prototheca, Helicosporidum), are also known, as well as the land plants (mosses, ferns, angiosperms, etc.). Single-gene phylogenies and phylogenomics of plastid genes have strongly supported a common origin of the primary plastids in the ancestor of Archaeplastida (Chu et al. 2004; Hagopian et al. 2004; Rodriguez-Ezpeleta et al. 2005). Cell biology also supports a unique endosymbiosis with a shared plastid protein import machinery (Palmer 2003; McFadden and van Dooren 2004; Price et al. 2012). Nuclear phylogenies are less supportive (Moreira et al. 2000; Rodriguez-Ezpeleta et al. 2005; Nozaki et al. 2007, 2009), but this supergroup is generally widely recognized.

\section{SAR}

This vast assemblage is the most recently recognized supergroup and, contrary to the other supergroups, its existence is exclusively supported by molecular data (i.e., phylogenomic analyses (Burki et al. 2007, 2008; Hackett et al. 2007; Rodriguez-Ezpeleta et al. 2007a) and a derived RAB1 paralog (Elias et al. 2009). It was originally named SAR as an acronym of its constituents: stramenopiles, alveolates, and Rhizaria (Burki et al. 2007). Stramenopiles (also known as heterokonts) embrace a very large diversity of protists, including, for example, ecologically important algal groups such as diatoms or large multicellular seaweeds (e.g., kelps), as well as heterotrophic, often parasitic species such as oomycetes and Blastocystis. Stramenopiles are typically characterized by two opposing flagella with tripartite flagellar hairs (mastigonemes) on the forward flagellum, but also include many lineages that lost one or both flagella (Cavalier-Smith 1986). They are well supported by molecular data (Ben Ali et al. 2002; Cavalier-Smith and Chao 2006; Riisberg et al. 2009). Alveolates are also extremely diverse, notably including the dinoflagellate algae, but also apicomplexan parasites such as the malaria agent Plasmodium or ciliate protozoans (e.g., Tetrahymena). The cortical alveoli, a system of vesicles supporting the plasma membrane, constitute a morphological synapomorphy for the alveolates (Cavalier-Smith 1991). Molecular phylogenies strongly support the monophyly of alveolates (e.g., Fast et al. 2002; Harper et al. 2005). Rhizaria is based on molecular characters only (e.g., Keeling 2001; Archibald et al. 2003; Nikolaev et al. 2004; Bass et al. 2005; Burki and Pawlowski 2006; Burki et al. 2010; Brown et al. 2012; Sierra et al. 2013). It includes naked and testate amoeboid, heterotrophic protists with filose or reticulose pseudopods such as foraminiferans and radiolarians. Some rhizarians are photosynthetic, including lineages in the euglyphids (e.g., Paulinella) and chlorarachniophytes (e.g., Bigelowiella). A large diversity of free-living flagellates and amoeboflagellates, sorocarpic (e.g., Guttulinopsis), and parasite protists also belong to this group (see Pawlowski and Burki 2009 for a review). One enigmatic parasite, Mikrocytos mackini, which infects and kills oysters, was recently shown to belong to Rhizaria and attracted attention because it likely possesses highly reduced mitochondrion-derived organelle (Burki et al. 2013).

\section{THE RISE OF SAR}

Before being members of SAR, stramenopiles and alveolates were part of another supergroup, chromalveolates, which has played a central role in shaping our understanding of eukaryotic evolution, particularly the origin and spread of secondary plastids of red algal origin (Keeling 2009). In addition to stramenopiles and alveolates, the four original constituent chromalveolate lineages also included two important 
protist groups: haptophytes and cryptomonads (Keeling 2004; Reyes-Prieto et al. 2007). Although many of these lineages are nonphotosynthetic or lack plastid altogether, the rational for grouping them into a monophyletic entity was based on the idea that the plastids of the chromalveolate taxa, which all share chlorophyll $c$, can be traced back to a single endosymbiotic event with a red alga (Cavalier-Smith 1999). Under this hypothesis, the secondary red plastid origin is unique and took place in the chromalveolate ancestor, and the numerous nonphotosynthetic lineages scattered among the chromalveolate tree were inferred to have lost their plastid and/or photosynthesis (Cavalier-Smith 1999). However, because of the absence of integrative molecular evidence supporting it, the chromalveolates have long been a controversial supergroup and it was recently remodeled in such a way that it has disappeared from the current consensus of the eukaryotic tree (Fig. 1) (Adl et al. 2012; Keeling 2013; Pawlowski 2013).

In phylogenetic terms, one condition of the chromalveolate hypothesis is that both the plastid and host (i.e., nuclear) trees must be consistent in showing the monophyly of alveolates, stramenopiles, haptophytes, and cryptomonads. From the plastid side, the monophyly has usually been recovered for three of these groups (Yoon et al. 2002; Khan et al. 2007). Alveolates, however, have proven nearly impossible to fit into this molecular framework because their plastid genomes are generally highly reduced, providing only few genes for comparative analyses (Köhler et al. 1997; Green 2004). But this was before the recent unexpected discovery of deep-branching relatives of apicomplexans (e.g., Chromera, Vitrella) (Moore et al. 2008), members of alveolates, which possess more gene-rich plastid genomes (Janouskovec et al. 2010). When the genomes of these species were compared to those of other chromalveolates, the tree that emerged showed a robust union between the alveolate and stramenopile plastids, and recovered the global monophyly of the red plastids also including haptophytes and cryptomonads (which were most closely related to each other), albeit with lower support (Ja- nouskovec et al. 2010). Early nuclear phylogenies based on single genes also recovered a close association between alveolates and stramenopiles (Van de Peer et al. 1996; Harper et al. 2005). Phylogenomics largely confirmed this observation and, at the same time, produced trees in which haptophytes and cryptomonads shared a common ancestor, congruent with the plastid topology (Hackett et al. 2007; Patron et al. 2007; Burki et al. 2009). This latter association was also supported by a unique shared insertion of a laterally transferred rpl36 gene into the plastids of haptophytes and cryptomonads (Rice and Palmer 2006), which led some to propose the name Hacrobia to accommodate the body of evidence in favor of a common origin between these two groups (Okamoto et al. 2009).

However, what appeared to be a consistent scenario rapidly became challenged by the accumulating genetic data from diverse species as well as evidence against the monophyly of its original constituents. First, several phylogenomic studies showed that Rhizaria branched together with alveolates and stramenopiles (the SAR group) to the exclusion of haptophytes and cryptomonads, whose exact positions remained unresolved (Burki et al. 2007, 2008, 2009; Hackett et al. 2007; Rodriguez-Ezpeleta et al. 2007a). This was significant because Rhizaria include mostly heterotrophic groups and only two known photosynthetic lineages (chlorarachniophytes and Paulinella), neither of which possesses plastids of red algal origin. Thus, under the chromalveolate hypothesis, the SAR relationships imply that the ancestor of Rhizaria had a red-algal-derived plastid, which was lost before their diversification. At first glance, this might not substantially alter the chromalveolate hypothesis: Regardless of how many species belong to Rhizaria, only one more loss of an ancestral red plastid (out of many genuinely assumed) is required to explain the current plastid distribution, provided that SAR is closely related to Hacrobia.

In addition to Rhizaria, however, phylogenetic analyses showed that several other heterotrophic lineages were linked to the chromalveolates, further challenging the hypothesis. 
Specifically, telonemids, centrohelids, katablepharids, and picobiliphytes (now Picozoa) (Seenivasan et al. 2013) have all been inferred as sister to either haptophytes or cryptomonads (Shalchian-Tabrizi et al. 2006; Not et al. 2007; Burki et al. 2009), but these associations are generally poorly resolved, with the exception of katablepharids, which is robustly related to cryptomonads (Okamoto and Inouye 2005; Burki et al. $2012 \mathrm{~b}$ ). Nevertheless, the addition of new plastid-lacking lineages compromised both the hacrobian and chromalveolate hypotheses because both are based on a common plastid origin (Cavalier-Smith 1999; Okamoto et al. 2009). Proponents of the chromalveolate hypothesis, however, can always put forward the argument of plastid loss to explain these relationships, an argument that is difficult to refute until the prevalence of plastid loss among eukaryotes is better understood.

More problematic is evidence calling into question the existence of Hacrobia; in contrast to earlier reports, a recent phylogenomic study did not recover the association between haptophytes and cryptomonads, but instead showed haptophytes branching closer to SAR, whereas cryptomonads were sister to Archaeplastida (Burki et al. 2012b). These relationships were generally weakly supported, in particular, the position of cryptomonads, and thus require further testing before one can safely dismantle theHacrobia hypothesis. But, by recovering cryptomonads distantly related to SAR and haptophytes, this study shifted attention on the position of this group as key to infer red plastid evolution (Burki et al. 2012b). Indeed, if the cryptomonad-Archaeplastida grouping is confirmed, it would not only invalidate the condition of a shared origin between all chromalveolate lineages in both nuclear and plastid phylogenies, it would also conflict with plastid phylogenies that strongly group haptophytes and cryptomonads (Janouskovec et al. 2010). Furthermore, a study evaluating the phylogenomic signal across the three genomic compartments (nuclear, plastid, and mitochondrial) in chromalveolate taxa reported discrepancies too high to be explained by a common origin of both the plastid and host lineages (Baurain et al. 2010). Altogether, these observations have forged the basis for alternative scenarios to the chromalveolate hypothesis: scenarios in which red plastids spread across the tree not by means of vertical inheritance, but through more complex serial eukaryote-to-eukaryote endosymbioses (Lane and Archibald 2008; Sanchez Puerta and Delwiche 2008; Archibald 2009; Bodyl et al. 2009; Baurain et al. 2010; Dorrell and Smith 2011).

\section{DIGGING FOR THE ROOT}

In addition to improving the resolution of the eukaryotic tree, knowing precisely where the root lies is essential to give directionality to evolution and go beyond the classical star-like representation of the supergroups. This fundamental issue has proven extremely difficult to tackle because it refers to a prohibitively ancient event: the last eukaryotic common ancestor. The position of the root is generally considered unresolved, but a few hypotheses have emerged. The most straightforward approach to root a phylogenetic tree is to use an outgroup, which often consists of one or several lineages known to stem from the base of the group of interest. In the case of eukaryotes, one possible outgroup is to be found within prokaryotes. This is problematic because even the closest prokaryotic outgroup (Archaebacteria) represents a considerable evolutionary distance from eukaryotes, which could potentially lead to the LBA artefact (Felsenstein 1981). If fact, analyses including prokaryotes usually produced suspicious phylogenies in which the fastest evolving eukaryotes branched off close to the base of the tree, attracted to the distant outgroup (Philippe et al. 2000b; Ciccarelli et al. 2006; Williams et al. 2012).

To reduce the outgroup-to-ingroup distance, some researchers have used genes derived from the $\alpha$-proteobacterium endosymbiotic progenitor of mitochondria (Derelle and Lang 2012). This analysis placed the eukaryotic root between unikonts and everything else (often referred to as bikonts) (Cavalier-Smith 2002), supporting what is perhaps the most prevailing view for the original bifurcation in the eukary- 


\section{F. Burki}

otic tree. Two rare genomic changes have also supported the basal unikont-bikont split: (1) unikonts have ancestral, bacterial-like dihydrofolate reductase (DHFR) and thymidylate synthase (TS) genes, whereas bikonts have derived and fused version of these two genes (Philippe et al. 2000b; Stechmann and Cavalier-Smith 2002, 2003); and (2) unikonts have a unique glycine insertion to myosin class II, whereas this paralog is absent from bikonts (Richards and Cavalier-Smith 2005). Following a parsimonious argumentation, these two signatures were taken as evidence for the monophyly of unikonts and bikonts, and a root position outside of both groups. The unikont-bikont bifurcation was proposed to coincide with a fundamental difference of the flagellar apparatus: unikonts have retained the ancestral organization with one basal body anchoring one flagellum, whereas bikonts are ancestrally biflagellated with two basal bodies (Cavalier-Smith 2002; Stechmann and Cavalier-Smith 2002, 2003).

However, the sequencing of new enigmatic lineages has repetitively challenged the unikontbikont bifurcation. For example, although the protistean apuzomonads (e.g., Thecamonas) are by essence bikonts (with two basal bodies and two flagella) and possess the fused TS-DHFR, they were shown to be related to unikonts (Kim et al. 2006; Brown et al. 2012; Derelle and Lang 2012). Similarly, the breviate amoeba (e.g., Breviata), which harbors two basal bodies (but only one flagellum), turned out to be a deep-branching unikont (Minge et al. 2009; Roger and Simpson 2009; Brown et al. 2013). These data suggest that the true unikonts, in addition to some protists not fitting with the original description of a monoflagellated ancestry and separate TS and DHFR genes, may form a clade, but it seems increasingly untenable that this group was ancestrally unikont with one basal body. To formalize this taxon without reflecting the controversial ancestral state, the name Amorphea was recently introduced (Adl et al. 2012).

Other analyses have further exacerbated the uncertain position of the eukaryotic root. Recently, a study looking at the taxonomic distribution of the endoplasmic reticulum (ER)-mi- tochondria encounter structure, which tethers mitochondria to the ER membrane, showed that the root is most consistently placed between Amorphea + excavates and all other eukaryotes (Wideman et al. 2013). Researchers investigating a new class of rare genomic changes involving multiple, conserved amino acid residues inferred the initial split in eukaryote evolution between Archaeplastida and everything else (Rogozin et al. 2009). A different approach showed that by minimizing the number of gene duplications and loss across 20 genes, the most parsimonious root was found to lie inbetween opisthokonts and the rest of eukaryotes (Katz et al. 2012). In yet another scenario, the root was proposed to be deep within excavates (thus invalidating the monophyletic origin of this supergroup), possibly between Euglenozoa and all other eukaryotes, based on the absence of the mitochondrial outer-membrane channel Tom40 and the DNA replication origin-recognition complexes, both ancestral bacterial features (Cavalier-Smith 2010b). Most recently, the use of 37 nuclear-encoded proteins of close bacterial ancestry, most of which are of mitochondrial function, positioned the root between excavates and the rest of eukaryotes ( $\mathrm{He}$ et al. 2014). The list of hypotheses goes on, and it may be some time before the root is dug out, but when its position is revealed with more consistency, it will have a fundamental impact on our understanding of how the eukaryotic supergroups relate to one another.

\section{DEEP RELATIONSHIPS AMONG EUKARYOTES}

In an attempt to best reflect the current view of eukaryotic relationships, I present a rooted tree with the origin of eukaryotes between Amorphea and everything else, but also indicate five alternative rooting positions (Fig. 1). Amorphea includes opisthokonts, Amoebozoa, and several protist lineages of uncertain phylogenetic placement, such as apusomonads, ancryomonads, and the breviate amoebae. (Heiss et al. 2011; Katz et al. 2011; Brown et al. 2013). The rest of eukaryotes comprises excavates and the recently erected mega-clade Diaphoretickes 
The Tree of Eukaryotes

(Adl et al. 2012), which recognizes the SAR and Archaeplastida clade (Burki et al. 2008) and corresponds to the corticates of Cavalier-Smith (2010a). Other incertae sedis lineages, such as haptophytes, cryptomonads, katablepharids, telonemids, centrohelids, Rappemonads, and Palpitomonas, may also belong to Diaphoretickes, as compiled from several phylogenetic results (Rodriguez-Ezpeleta et al. 2007a; Burki et al. 2009; Hampl et al. 2009; Yabuki et al. 2010; Kim et al. 2011; Brown et al. 2012). The branching pattern within Diaphoretickes is generally poorly resolved, but haptophytes may be sister to SAR (Burki et al. 2012b). The position of cryptomonads, although ambiguous, has recently shown affinities to Archaeplastida (Burki et al. 2012b). The other lineages have failed to show reliable phylogenetic placement and remain enigmatic.

With this evolutionary framework in mind, one group, Collodictyon, stands out as particularly remarkable. Collodictyon is an omnivorous amoeboflagellated cell with a mysterious position in the tree of eukaryotes. It possesses an eclectic mix of cellular features, such as a ventral feeding groove typical of excavates and amoebozoan-like pseudopods, which make pinpointing its phylogenetic position difficult but desirable (Klaveness 1995; Brugerolle et al. 2002). When its position was investigated using a large phylogenomic data set, Collodictyon branched off early in eukaryote evolution, close to the Amorphea-bikont bifurcation (Fig. 1), suggesting that its morphological characteristics may represent some of the ancestral conditions of the eukaryotic cell (Zhao et al. 2012). With the potential exception of the contentious excavate Malawimonas, which has proven impossible to unambiguously assign to any large group of eukaryotes and showed affinities to Collodictyon, this branch of the eukaryotic tree is known to include only one other genus (Diphylleia), a view supported by observations of very low genetic diversity of Collodictyon-like sequences in environmental surveys (Zhao et al. 2012). Given a root as in Figure 1, this group may represent the first confirmed case of a lineage that diverged after the Amorphea-bikont split, but before the subsequent diversification of these two groups.

\section{CONCLUDING REMARKS}

Over the last 10 years, phylogenomics has led to important refinements of the global tree of eukaryotes. Most of the large building blocks of the tree (the supergroups) predating the genomic era have been reinforced by the analyses of larger data sets, but some were also shuffled into different arrangements. The increased phylogenetic power of phylogenomics helped resolve the relationships between the supergroups, providing new hypotheses for the deep backbone of the tree. It also allowed the placement of orphan taxa that had eluded proper classification until more data became available. At the same time, new challenges have appeared and several key lineages remain of unknown evolutionary origin. It is clear that the dawn of eukaryote evolution and subsequent diversification will not be fully understood until these enigmatic lineages find a home and the root of the tree is characterized. What's more, as we explore incertae sedis taxa, classical microscopy as well as next-generation environmental surveys and single-cell genomics will undoubtedly reveal new essential protist taxa. But the exciting news is: Technological advancements such as sequencing preparation from nano-quantities of material now allow one to tackle these taxa from a genomic perspective, even when cell cultures cannot be established (Yoon et al. 2011).

Resolving the tree of eukaryotes will necessitate continuing the integrative approach blending morphology, single-gene phylogeny, and phylogenomics including all diversity. It will also require more reliable ways of assembling genomic data and the development of new methods to extract the phylogenetic information contained in these genomes. Importantly, the pervasiveness of HGT in eukaryotes, in particular, the genes transferred from plastids (endosymbiotic gene transfer), will need to be systematically evaluated. Presently, the fierce debate over the global impact of HGT on eukaryote evolution and its harmful consequences on phylogenomics is far from a consensus (Moustafa et al. 2009; Stiller 2011; Burki et al. 2012a; Chan et al. 2012; Deschamps and Moreira 2012). Eukaryote evolution started off more 
than a billion years ago and reconstructing the twists and turns that led to the diversity we observe today is a tremendously difficult task, but a task that is both fascinating and on its way to be deciphered.

\section{ACKNOWLEDGMENTS}

I express my deepest gratitude to Yana Eglit, Thierry Heger, Jan Pawlowski, David Smith, and Barbara Yermen for critical and constructive reading of an earlier version of this manuscript. My research is supported by a grant from the Tula Foundation to the Centre for Microbial Diversity and Evolution.

\section{REFERENCES}

Adl SM, Simpson AG, Farmer MA, Andersen RA, Anderson OR, Barta JR, Bowser SS, Brugerolle G, Fensome RA, Fredericq S, et al. 2005. The new higher level classification of eukaryotes with emphasis on the taxonomy of protists. J Eukaryot Microbiol 52: 399-451.

Adl SM, Simpson AG, Lane CE, Lukes J, Bass D, Bowser SS, Brown MW, Burki F, Dunthorn M, Hampl V, et al. 2012. The revised classification of eukaryotes. J Eukaryot Microbiol 59: 429-514.

Archibald JM. 2009. The puzzle of plastid evolution. Curr Biol 19: R81-R88.

Archibald JM, Longet D, Pawlowski J, Keeling PJ. 2003. A novel polyubiquitin structure in Cercozoa and Foraminifera: Evidence for a new eukaryotic supergroup. Mol Biol Evol 20: 62-66.

Baldauf SL. 1999. A search for the origins of animals and fungi: Comparing and combining molecular data. Am Nat 154: S178-S188.

Baldauf SL. 2003. The deep roots of eukaryotes. Science 300: 1703-1706.

Baldauf SL, Palmer JD. 1993. Animals and fungi are each other's closest relatives: Congruent evidence from multiple proteins. Proc Natl Acad Sci 90: 11558-11562.

Baldauf SL, Roger AJ, Wenk-Siefert I, Doolittle W. 2000. A kingdom-level phylogeny of eukaryotes based on combined protein data. Science 290: 972-977.

Bapteste E, Brinkmann H, Lee JA, Moore DV, Sensen CW, Gordon P, Duruflé L, Gaasterland T, Lopez P, Müller M, et al. 2002. The analysis of 100 genes supports the grouping of three highly divergent amoebae: Dictyostelium, Entamoeba, and Mastigamoeba. Proc Natl Acad Sci 99: 1414-1419.

Bass D, Moreira D, López-García P, Polet S, Chao EE, von der Heyden S, Pawlowski J, Cavalier-Smith T. 2005. Polyubiquitin insertions and the phylogeny of Cercozoa and Rhizaria. Protist 156: 149-161.

Baurain D, Brinkmann H, Petersen J, Rodriguez-Ezpeleta N, Stechmann A, Demoulin V, Roger AJ, Burger G, Lang BF,
Philippe HH. 2010. Phylogenomic evidence for separate acquisition of plastids in cryptophytes, haptophytes, and stramenopiles. Mol Biol Evol 27: 1698-1709.

Ben Ali A, De Baere R, De Wachter R, Van de Peer Y. 2002. Evolutionary relationships among heterokont algae (the autotrophic stramenopiles) based on combined analyses of small and large subunit ribosomal RNA. Protist 153: $123-132$.

Bodyl A, Stiller JW, Mackiewicz P. 2009. Chromalveolate plastids: Direct descent or multiple endosymbioses? Trends Ecol Evol 24: 1-119; author reply 121-122.

Brown JR, Doolittle WF. 1995. Root of the universal tree of life based on ancient aminoacyl-tRNA synthetase gene duplications. Proc Natl Acad Sci 92: 2441-2445.

Brown MW, Spiegel FW, Silberman JD. 2009. Phylogeny of the "forgotten" cellular slime mold, Fonticula alba, reveals a key evolutionary branch within Opisthokonta. Mol Biol Evol 26: 2699-2709.

Brown MW, Kolisko M, Silberman JD, Roger AJ. 2012. Aggregative multicellularity evolved independently in the eukaryotic supergroup Rhizaria. Curr Biol 22: 11231127.

Brown MW, Sharpe SC, Silberman JD, Heiss AA, Lang F, Simpson AG, Roger AJ. 2013. Phylogenomics demonstrates that breviate flagellates are related to opishokonts and apusomonads. Proc Biol Sci 280: 20131755.

Brugerolle G, Bricheux G, Philippe HH, Coffe G. 2002. Collodictyon triciliatum and Diphylleia rotans (= Aulacomonas submarina) form a new family of flagellates (Collodictyonidae) with tubular mitochondrial cristae that is phylogenetically distant from other flagellate groups. Protist 153: 59-70.

Bui ET, Bradley PJ, Johnson PJ. 1996. A common evolutionary origin for mitochondria and hydrogenosomes. Proc Natl Acad Sci 93: 9651-9656.

Burki F, Pawlowski J. 2006. Monophyly of Rhizaria and multigene phylogeny of unicellular bikonts. Mol Biol Evol 23: 1922-1930.

Burki F, Shalchian-Tabrizi K, Minge M, Skjaeveland A, Nikolaev SI, Jakobsen KS, Pawlowski J. 2007. Phylogenomics reshuffles the eukaryotic supergroups. PLOS ONE 2: e790.

Burki F, Shalchian-Tabrizi K, Pawlowski J. 2008. Phylogenomics reveals a new "megagroup" including most photosynthetic eukaryotes. Biol Lett 4: 366-369.

Burki F, Inagaki Y, Bråte J, Archibald JM, Keeling PJ, Cavalier-Smith TT, Sakaguchi M, Hashimoto T, Horak A, Kumar S, et al. 2009. Large-scale phylogenomic analyses reveal that two enigmatic protist lineages, telonemia and centroheliozoa, are related to photosynthetic chromalveolates. Genome Biol Evol 1: 231-238.

Burki F, Kudryavtsev A, Matz MV, Aglyamova GV, Bulman S, Fiers M, Keeling PJ, Pawlowski J. 2010. Evolution of Rhizaria: New insights from phylogenomic analysis of uncultivated protists. BMC Evol Biol 10: 377.

Burki F, Flegontov P, Obornik M, Cihlar J, Pain A, Lukes J, Keeling PJ. 2012a. Reevaluating the green versus red signal in eukaryotes with secondary plastid of red algal origin. Genome Biol Evol 4: 626-635.

Burki F, Okamoto N, Pombert J-FF, Keeling PJ. 2012b. The evolutionary history of haptophytes and cryptophytes: 
Phylogenomic evidence for separate origins. Proc R Soc Lond B Biol Sci 279: 2246-2254.

Burki F, Corradi NN, Sierra R, Pawlowski J, Meyer GR, Abbott CL, Keeling PJ. 2013. Phylogenomics of the intracellular parasite Mikrocytos mackini reveals evidence for a mitosome in rhizaria. Curr Biol 23: 1541-1547.

Cavalier-Smith T. 1983. A 6 kingdom classification and a unified phylogeny (ed. Schwemmler W, Schenk HEA). De Gruyter, Berlin.

Cavalier-Smith T. 1986. The Kingdom Chromista: Origin and systematics (ed. Round FE, Chapman DJ). Biopress, Bristol, UK.

Cavalier-Smith T. 1987. Eukaryotes with no mitochondria. Nature 326: 332-333.

Cavalier-Smith T. 1989. Molecular phylogeny. Archaebacteria and Archezoa. Nature 339: 100-101.

Cavalier-Smith T. 1991. Cell diversification in heterotrophic flagellates (ed. Patterson DJ, Larsen D). Clarendon, Oxford.

Cavalier-Smith T. 1999. Principles of protein and lipid targeting in secondary symbiogenesis: Euglenoid, dinoflagellate, and sporozoan plastid origins and the eukaryote family tree. J Eukaryot Microbiol 46: 347-366.

Cavalier-Smith T. 2002. The phagotrophic origin of eukaryotes and phylogenetic classification of Protozoa. Int J Syst Evol Micr 52: 297-354.

Cavalier-Smith T. 2010a. Deep phylogeny, ancestral groups and the four ages of life. Philos Trans R Soc Lond B Biol Sci 365: $111-132$.

Cavalier-Smith T. 2010b. Kingdoms Protozoa and Chromista and the eozoan root of the eukaryotic tree. Biol Lett 6: 342-345.

Cavalier-Smith T, Chao EE. 1995. The Opalozoan Apusomonas is related to the common ancestor of animals, fungi, and choanoflagellates. Proc R Soc Lond B Biol Sci 261: $1-6$.

Cavalier-Smith T, Chao EE. 2006. Phylogeny and megasystematics of phagotrophic heterokonts (kingdom Chromista). J Mol Biol 62: 388-420.

Chan CX, Soares MB, Bonaldo MF, Wisecaver JH, Hackett JD, Anderson DM, Erdner DL, Bhattacharya D. 2012. Analysis of Alexamdrium tamarense (Dinophyceae) genes reveals the complex evolutionary history of a microbial eukaryote. J Phycol 48: 1130-1142.

Chu KH, Qi J, Yu Z, Anh V. 2004. Origin and phylogeny of chloroplasts revealed by a simple correlation analysis of complete genomes. Mol Biol Evol 21: 200-206.

Ciccarelli FD, Doerks T, von Mering C, Creevey CJ, Snel B, Bork P. 2006. Toward automatic reconstruction of a highly resolved tree of life. Science 311: 1283-1287.

Clark CG, Cross GA. 1988. Small-subunit ribosomal RNA sequence from Naegleria gruberi supports the polyphyletic origin of amoebas. Mol Biol Evol 5: 512-518.

Clark CG, Roger AJ. 1995. Direct evidence for secondary loss of mitochondria in Entamoeba histolytica. Proc Natl Acad Sci 92: 6518-6521.

Copeland H. 1938. The kingdoms of organisms. Q Rev Biol 13: $383-420$.

Corradi NN, Pombert J-FF, Farinelli L, Didier ES, Keeling PJ. 2010. The complete sequence of the smallest known nu- clear genome from the microsporidian Encephalitozoon intestinalis. Nat Commun 1: 77.

del Campo J, Ruiz-Trillo I. 2013. Environmental survey meta-analysis reveals hidden diversity among unicellular opisthokonts. Mol Biol Evol 30: 802-805.

Delsuc F, Brinkmann H, Philippe HH. 2005. Phylogenomics and the reconstruction of the tree of life. Nat Rev Genet 6 : 361-375.

Derelle R, Lang BF. 2012. Rooting the eukaryotic tree with mitochondrial and bacterial proteins. Mol Biol Evol 29: 1277-1289.

Deschamps P, Moreira D. 2012. Reevaluating the green contribution to diatom genomes. Genome Biol Evol 4: $795-$ 800.

Dorrell RG, Smith AG. 2011. Do red and green make brown?: Perspectives on plastid acquisitions within chromalveolates. Eukaryot Cell 10: 856-868.

Douglas SE, Zauner S, Fraunholz M, Beaton M, Penny S, Deng LT, Wu X, Reith M, Cavalier-Smith T, Maier UG. 2001. The highly reduced genome of an enslaved algal nucleus. Nature 410: 1091-1096.

Eisen JA. 1998. Phylogenomics: Improving functional predictions for uncharacterized genes by evolutionary analysis. Genome Res 8: 163-167.

Elias M, Patron NJ, Keeling PJ. 2009. The RAB family GTPase Rab1A from Plasmodium falciparum defines a unique paralog shared by chromalveolates and rhizaria. $J$ Eukaryot Microbiol 56: 348-356.

Embley TM, Hirt RP. 1998. Early branching eukaryotes? Curr Opin Genet Dev 8: 624-629.

Embley TM, Martin WF. 2006. Eukaryotic evolution, changes and challenges. Nature 440: 623-630.

Fahrni JF, Bolivar I, Berney C, Nassonova E, Smirnov A, Pawlowski J. 2003. Phylogeny of lobose amoebae based on actin and small-subunit ribosomal RNA genes. Mol Biol Evol 20: 1881-1886.

Fast NM, Logsdon JM, Doolittle W. 1999. Phylogenetic analysis of the TATA box binding protein (TBP) gene from Nosema locustae: Evidence for a microsporidiafungi relationship and spliceosomal intron loss. Mol Biol Evol 16: 1415-1419.

Fast NM, Xue L, Bingham S, Keeling PJ. 2002. Re-examining alveolate evolution using multiple protein molecular phylogenies. J Eukaryot Microbiol 49: 30-37.

Felsenstein J. 1981. Evolutionary trees from DNA sequences: A maximum likelihood approach. J Mol Biol 17: 368376.

Foster PG. 2004. Modeling compositional heterogeneity. Syst Biol 53: 485-495.

Friedman S, Debrunner-Vossbrinck B, Woese CR. 1987. Ribosomal RNA sequence suggests microsporidia are extremely ancient eukaryotes. Nature 326: 411-414.

Gilson PR, Su V, Slamovits CH, Reith ME, Keeling PJ, McFadden GI. 2006. Complete nucleotide sequence of the chlorarachniophyte nucleomorph: Nature's smallest nucleus. Proc Natl Acad Sci 103: 9566.

Goldberg AV, Molik S, Tsaousis AD, Neumann K, Kuhnke G, Delbac F, Vivarès CP, Hirt RP, Lill R, Embley TM. 2008. Localization and functionality of microsporidian iron-sulphur cluster assembly proteins. Nature 452 : $624-$ 628. 
F. Burki

Green BR. 2004. The chloroplast genome of dinoflagellates-A reduced instruction set? Protist 155: 23-31.

Hackett JD, Yoon HS, Li S, Reyes-Prieto A, Rümmele SE, Bhattacharya D. 2007. Phylogenomic analysis supports the monophyly of cryptophytes and haptophytes and the association of rhizaria with chromalveolates. $\mathrm{Mol}$ Biol Evol 24: 1702-1713.

Haeckel E. 1866. Generelle Morphologie der Organismen. Reimer, Berlin.

Hagopian JC, Reis M, Kitajima JP, Bhattacharya D, de Oliveira MC. 2004. Comparative analysis of the complete plastid genome sequence of the red alga Gracilaria tenuistipitata var. liui provides insights into the evolution of rhodoplasts and their relationship to other plastids. $J \mathrm{Mol}$ Biol 59: 464-477.

Hampl V, Hug L, Leigh JW, Dacks JB, Lang BF, Simpson AGB, Roger AJ. 2009. Phylogenomic analyses support the monophyly of Excavata and resolve relationships among eukaryotic "supergroups." Proc Natl Acad Sci 106: $3859-3864$.

Harper JT, Waanders E, Keeling PJ. 2005. On the monophyly of chromalveolates using a six-protein phylogeny of eukaryotes. Int J Syst Evol Micr 55: 487-496.

He D, Fiz-Palacios O, Fu C-J, Fehling J, Tsai C-C, Baldauf SL. 2014. An alternative root for the eukaryote tree of life. Curr Biol 24: 465-470.

Heiss AA, Walker G, Simpson AGB. 2011. The ultrastructure of Ancyromonas, a eukaryote without supergroup affinities. Protist 162: 373-393.

Hirt RP, Logsdon JM, Healy B, Dorey MW, Doolittle W, Embley TM. 1999. Microsporidia are related to Fungi: Evidence from the largest subunit of RNA polymerase II and other proteins. Proc Natl Acad Sci 96: 580-585.

Hjort K, Goldberg AV, Tsaousis AD, Hirt RP, Embley TM. 2010. Diversity and reductive evolution of mitochondria among microbial eukaryotes. Philos Trans R Soc Lond B Biol Sci 365: 713-727.

Ho SY, Jermiin L. 2004. Tracing the decay of the historical signal in biological sequence data. Syst Biol 53: 623-637.

Iwamoto M, Pi M, Kurihara M, Morio T, Tanaka Y. 1998. A ribosomal protein gene cluster is encoded in the mitochondrial DNA of Dictyostelium discoideum: UGA termination codons and similarity of gene order to Acanthamoeba castellanii. Curr Genet 33: 304-310.

James TY, Pelin A, Bonen L, Ahrendt S, Sain D, Corradi N, Stajich JE. 2013. Shared signatures of parasitism and phylogenomics unite Cryptomycota and Microsporidia. Curr Biol 23: 1-6.

Janouskovec J, Horak A, Obornik M, Lukes J, Keeling PJ 2010. A common red algal origin of the apicomplexan, dinoflagellate, and heterokont plastids. Proc Natl Acad Sci 107: 10949-10954.

Jeffroy O, Brinkmann H, Delsuc F, Philippe H. 2006. Phylogenomics: The beginning of incongruence? Trends $\mathrm{Ge}$ net 22: 225-231.

Jermiin L, Ho SY, Ababneh F, Robinson J, Larkum AW. 2004. The biasing effect of compositional heterogeneity on phylogenetic estimates may be underestimated. Syst Biol 53: 638-643.

Jones MD, Forn I, Gadelha C, Egan MJ, Bass D, Massana R, Richards TA. 2011a. Discovery of novel intermediate forms redefines the fungal tree of life. Nature 474: 200 203.

Jones MD, Richards TA, Hawksworth DL, Bass D. 2011b. Validation and justification of the phylum name Cryptomycota phyl. nov. IMA Fungus 2: 173-175.

Kamaishi T, Hashimoto T, Nakamura Y, Nakamura F, Murata S, Okada N, Okamoto K, Shimizu M, Hasegawa M. 1996. Protein phylogeny of translation elongation factor EF- $1 \alpha$ suggests microsporidians are extremely ancient eukaryotes. J Mol Biol 42: 257-263.

Karpov SA, Mikhailov KV, Mirzaeva GS, Mirabdullaev IM, Mamkaeva KA, Titova NN, Aleoshin VV. 2013. Obligately phagotrophic aphelids turned out to branch with the earliest-diverging fungi. Protist 164: 195-205.

Katz LA, Grant J, Parfrey LW, Gant A, O'Kelly CJ, Anderson OR, Molestina RE, Nerad T. 2011. Subulatomonas tetraspora nov. gen. nov. sp. is a member of a previously unrecognized major clade of eukaryotes. Protist 162: 762-773.

Katz LA, Grant JR, Parfrey LW, Burleigh JG. 2012. Turning the crown upside down: Gene tree parsimony roots the eukaryotic tree of life. Syst Biol 61: 653-660.

Keeling PJ. 1998. A kingdom's progress: Archezoa and the origin of eukaryotes. Bioessays 20: 87-95.

Keeling PJ. 2001. Foraminifera and Cercozoa are related in actin phylogeny: Two orphans find a home? Mol Biol Evol 18: 1551-1557.

Keeling PJ. 2004. Diversity and evolutionary history of plastids and their hosts. Am J Bot 91: 1481-1493.

Keeling PJ. 2009. Chromalveolates and the evolution of plastids by secondary endosymbiosis. $J$ Eukaryot Microbiol 56: $1-8$.

Keeling PJ. 2013. The number, speed, and impact of plastid endosymbioses in eukaryotic evolution. Annu Rev Plant Biol 64: 27.1-27.25.

Keeling PJ, Doolittle WF. 1996. A non-canonical genetic code in an early diverging eukaryotic lineage. $E M B O J$ 15: $2285-2290$.

Keeling PJ, Slamovits CH. 2005. Causes and effects of nuclear genome reduction. Curr Opin Genet Dev 15: 601608.

Keeling PJ, Burger G, Durnford DG, Lang BF, Lee RW, Pearlman RE, Roger AJ, Gray MW. 2005. The tree of eukaryotes. Trends Ecol Evol 20: 670-676.

Khan H, Parks N, Kozera C, Curtis BA, Parsons BJ, Bowman S, Archibald JM. 2007. Plastid genome sequence of the cryptophyte alga Rhodomonas salina CCMP1319: Lateral transfer of putative DNA replication machinery and a test of chromist plastid phylogeny. Mol Biol Evol 24: $1832-1842$.

Kim E, Simpson AG, Graham LE. 2006. Evolutionary relationships of apusomonads inferred from taxon-rich analyses of 6 nuclear encoded genes. Mol Biol Evol 23: 24552466.

Kim E, Harrison JW, Sudek S, Jones MD, Wilcox HM, Richards TA, Worden AZ, Archibald JM. 2011. Newly identified and diverse plastid-bearing branch on the eukaryotic tree of life. Proc Natl Acad Sci 108: 1496-1500.

Klaveness D. 1995. Collodictyon triciliatum H.J. Carter (1865) — A common but fixation-sensitive algivorous fla- 
gellate from the limnopelagial. Nord J Freshw Res 70: 3-11.

Klenk H-P, Zilllg W, Lanzendorfer M, Grampp B, Palm P. 1995. Location of protist lineages in a phylogenetic tree inferred from sequences of DNA-dependent RNA polymerases. Archiv für Protistenkunde 145: 221-230.

Knoll AH. 1992. The early evolution of eukaryotes: A geological perspective. Science 256: 622-627.

Köhler S, Delwiche CF, Denny PW, Tilney LG, Webster P, Wilson RJ, Palmer JD, Roos DS. 1997. A plastid of probable green algal origin in Apicomplexan parasites. Science 275: 1485-1489.

Kolisko M, Cepicka I, Hampl V, Leigh J, Roger AJ, Kulda J, Simpson AG, Flegr J. 2008. Molecular phylogeny of diplomonads and enteromonads based on SSU rRNA, $\alpha-$ tubulin and HSP90 genes: Implications for the evolutionary history of the double karyomastigont of diplomonads. BMC Evol Biol 8: 205.

Lane CE, Archibald JM. 2008. The eukaryotic tree of life: Endosymbiosis takes its TOL. Trends Ecol Evol 23: 268275.

Lane CE, van den Heuvel K, Kozera C, Curtis BA, Parsons BJ, Bowman S, Archibald JM. 2007. Nucleomorph genome of Hemiselmis andersenii reveals complete intron loss and compaction as a driver of protein structure and function. Proc Natl Acad Sci 104: 19908-19913.

Lara E, Moreira D, López-García P. 2010. The environmental clade LKM11 and Rozella form the deepest branching clade of fungi. Protist 161: 116-121.

Liu Y, Steenkamp E, Brinkmann H, Forget L, Philippe HH, Lang BF. 2009. Phylogenomic analyses predict sistergroup relationship of nucleariids and fungi and paraphyly of zygomycetes with significant support. BMC Evol Biol 9: 272.

Lonergan KM, Gray MW. 1996. Expression of a continuous open reading frame encoding subunits 1 and 2 of cytochrome c oxidase in the mitochondrial DNA of Acanthamoeba castellanii. J Mol Biol 257: 1019-1030.

Lopez P, Casane D, Philippe H. 2002. Heterotachy, an important process of protein evolution. Mol Biol Evol 19: $1-7$.

Lynch M, Conery JS. 2003. The origins of genome complexity. Science 302: 1401-1404.

Margulis L. 1971. Whittaker's five kingdoms of organisms: Minor revisions suggested by considerations of the origin of mitosis. Evolution 25: 242-245.

McFadden GI, van Dooren GG. 2004. Evolution: Red algal genome affirms a common origin of all plastids. Curr Biol 14: R514-R516.

Minge MA, Silberman JD, Orr RJS, Cavalier-Smith T, Shalchian-Tabrizi K, Burki F, Skjaeveland A, Jakobsen KS. 2009. Evolutionary position of breviate amoebae and the primary eukaryote divergence. Proc $R$ Soc Lond B Biol Sci 276: 597-604.

Moore RB, Obornik M, Janouskovec J, Chrudimský T, Vancová M, Green DH, Wright SW, Davies NW, Bolch CJ, Heimann K, et al. 2008. A photosynthetic alveolate closely related to apicomplexan parasites. Nature 451: 959963.
Moreira D, Le Guyader H, Philippe H. 2000. The origin of red algae and the evolution of chloroplasts. Nature 405: 69-72.

Moustafa A, Beszteri B, Maier UG, Bowler C, Valentin K, Bhattacharya D. 2009. Genomic footprints of a cryptic plastid endosymbiosis in diatoms. Science 324: 17241726.

Nikolaev SI, Berney C, Fahrni JF, Bolivar I. 2004. The twilight of Heliozoa and rise of Rhizaria, an emerging supergroup of amoeboid eukaryotes. Proc Natl Acad Sci 101: 8066-8071.

Not FF, Valentin K, Romari K, Lovejoy C, Massana R, Töbe K, Vaulot D, Medlin LK. 2007. Picobiliphytes: A marine picoplanktonic algal group with unknown affinities to other eukaryotes. Science 315: 253-255.

Nozaki H, Iseki M, Hasegawa M, Misawa K, Nakada T, Sasaki N, Watanabe M. 2007. Phylogeny of primary photosynthetic eukaryotes as deduced from slowly evolving nuclear genes. Mol Biol Evol 24: 1592-1595.

Nozaki H, Maruyama S, Matsuzaki M, Nakada T, Kato S, Misawa K. 2009. Phylogenetic positions of Glaucophyta, green plants (Archaeplastida) and Haptophyta (Chromalveolata) as deduced from slowly evolving nuclear genes. Mol Phylogenet Evol 53: 872-880.

Okamoto N, Inouye I. 2005. The katablepharids are a distant sister group of the Cryptophyta: A proposal for Katablepharidophyta divisio nova/Kathablepharida phylum novum based on SSU rDNA and $\beta$-tubulin phylogeny. Protist 156: $163-179$.

Okamoto N, Chantangsi C, Horak A, Leander BS, Keeling PJ. 2009. Molecular phylogeny and description of the novel katablepharid Roombia truncata gen. et sp. nov., and establishment of the Hacrobia taxon nov. PLOS ONE 4: e7080.

Palmer JD. 2003. The symbiotic birth and spread of plastids: How many times and whodunit? J Phycol 39: 4-11.

Parfrey LW, Barbero E, Lasser E, Dunthorn M, Bhattacharya D, Patterson DJ, Katz LA. 2006. Evaluating support for the current classification of eukaryotic diversity. PLoS Genet 2: e220.

Patron NJ, Inagaki Y, Keeling PJ. 2007. Multiple gene phylogenies support the monophyly of cryptomonad and haptophyte host lineages. Curr Biol 17: 887-891.

Pawlowski J. 2013. The new micro-kingdoms of eukaryotes. BMC Biol 11: 40.

Pawlowski J, Burki F. 2009. Untangling the phylogeny of amoeboid protists. J Eukaryot Microbiol 56: 16-25.

Pawlowski J, Bolivar I, Fahrni JF, Cavalier-Smith T, Gouy M. 1996. Early origin of foraminifera suggested by SSU rRNA gene sequences. Mol Biol Evol 13: 445-450.

Philippe H. 2000. Opinion: Long branch attraction and protist phylogeny. Protist 151: 307-316.

Philippe H, Germot A, Moreira D. 2000a. The new phylogeny of eukaryotes. Curr Opin Genet Dev 10: 596-601.

Philippe H, Lopez P, Brinkmann H, Budin K, Germot A, Laurent J, Moreira D, Müller M, Le Guyader H. 2000b. Early-branching or fast-evolving eukaryotes? An answer based on slowly evolving positions. Proc R Soc Lond B Biol Sci 267: 1213-1221.

Philippe H, Delsuc F, Brinkmann H, Lartillot N. 2005. Phylogenomics. Annu Rev Ecol Evol Syst 36: 541-562. 
Philippe H, Brinkmann H, Lavrov DV, Littlewood DT, Manuel M, Wörheide G, Baurain D. 2011. Resolving difficult phylogenetic questions: Why more sequences are not enough. PLoS Biol 9: e1000602.

Price DC, Chan CX, Yoon HS, Yang EC, Qiu H, Weber AP, Schwacke R, Gross J, Blouin NA, Lane C, et al. 2012. Cyanophora paradoxa genome elucidates origin of photosynthesis in algae and plants. Science 335: 843-847.

Reyes-Prieto A, Weber AP, Bhattacharya D. 2007. The origin and establishment of the plastid in algae and plants. Annu Rev Genet 41: 147-168.

Rice DW, Palmer JD. 2006. An exceptional horizontal gene transfer in plastids: Gene replacement by a distant bacterial paralog and evidence that haptophyte and cryptophyte plastids are sisters. BMC Biol 4: 31 .

Richards TA, Cavalier-Smith T. 2005. Myosin domain evolution and the primary divergence of eukaryotes. Nature 436: $1113-1118$.

Riisberg I, Orr RJ, Kluge R, Shalchian-Tabrizi K, Bowers HA, Patil V, Edvardsen B, Jakobsen KS. 2009. Seven gene phylogeny of heterokonts. Protist 160: 191-204.

Rodriguez-Ezpeleta N, Brinkmann H, Burey SC, Roure B Burger G, Löffelhardt W, Bohnert HJ, Philippe H, Lang BF. 2005. Monophyly of primary photosynthetic eukaryotes: Green plants, red algae, and glaucophytes. Curr Biol 15: $1325-1330$.

Rodriguez-Ezpeleta N, Brinkmann H, Burger G, Roger AJ, Gray MW, Philippe H, Lang BF. 2007a. Toward resolving the eukaryotic tree: The phylogenetic positions of jakobids and cercozoans. Curr Biol 17: 1420-1425.

Rodriguez-Ezpeleta N, Brinkmann H, Roure B, Lartillot N, Lang BF, Philippe H. 2007b. Detecting and overcoming systematic errors in genome-scale phylogenies. Syst Biol 56: $389-399$.

Roger A. 1999. Reconstructing early events in eukaryotic evolution. Am Nat 154: S146-S163.

Roger AJ, Simpson AG. 2009. Evolution: Revisiting the root of the eukaryote tree. Curr Biol 19: R165-R167.

Roger AJ, Sandblom O, Doolittle W, Philippe H. 1999. An evaluation of elongation factor $1 \alpha$ as a phylogenetic marker for eukaryotes. Mol Biol Evol 16: 218-233.

Rogozin IB, Basu MK, Csürös M, Koonin EV. 2009. Analysis of rare genomic changes does not support the unikontbikont phylogeny and suggests cyanobacterial symbiosis as the point of primary radiation of eukaryotes. Genome Biol Evol 1: 99-113.

Ruiz-Trillo I, Roger AJ, Burger G, Gray MW, Lang BF. 2008. A phylogenomic investigation into the origin of metazoa. Mol Biol Evol 25: 664-672.

Sanchez Puerta MV, Delwiche CF. 2008. A hypothesis for plastid evolution in chromalveolates. J Phycol 44: 1097.

Seenivasan R, Sausen N, Medlin LK, Melkonian M. 2013. Picomonas judraskeda gen. et sp nov.: The first identified member of the Picozoa phylum nov., a widespread group of picoeukaryotes, formerly known as "picobiliphytes." PLOS ONE 8: e59565.

Shalchian-Tabrizi K, Eikrem W, Klaveness D, Vaulot D, Minge MA, Le Gall F, Romari K, Throndsen J, Botnen A, Massana R, et al. 2006. Telonemia, a new protist phylum with affinity to chromist lineages. Proc R Soc Lond B Biol Sci 273: 1833-1842.
Shalchian-Tabrizi K, Minge MA, Espelund M, Orr R, Ruden T, Jakobsen KS, Cavalier-Smith T. 2008. Multigene phylogeny of choanozoa and the origin of animals. PLoS ONE 3: e2098.

Sierra R, Matz MV, Aglyamova G, Pillet L, Decelle J, Not F, de Vargas C, Pawlowski J. 2013. Deep relationships of Rhizaria revealed by phylogenomics: A farewell to Haeckel's Radiolaria. Mol Phylogenet Evol 67: 53-59.

Simpson AG. 2003. Cytoskeletal organization, phylogenetic affinities and systematics in the contentious taxon Excavata (Eukaryota). Int J Syst Evol Micr 53: 1759-1777.

Simpson AG, Roger AJ. 2004. The real "kingdoms" of eukaryotes. Curr Biol 14: R693-R696.

Smirnov A, Nassonova E, Berney C, Fahrni J, Bolivar I, Pawlowski J. 2005. Molecular phylogeny and classification of the lobose amoebae. Protist 156: 129-142.

Sogin ML. 1991. Early evolution and the origin of eukaryotes. Curr Opin Genet Dev 1: 457-463.

Sogin ML, Elwood HJ, Gunderson JH. 1986. Evolutionary diversity of eukaryotic small-subunit rRNA genes. Proc Natl Acad Sci 83: 1383-1387.

Sogin ML, Gunderson JH, Elwood HJ, Alonso R. 1989. Phylogenetic meaning of the kingdom concept: An unusual ribosomal RNA from Giardia lamblia. Science 243: 75-77.

Stechmann A, Cavalier-Smith T. 2002. Rooting the eukaryote tree by using a derived gene fusion. Science 297: 89-91.

Stechmann A, Cavalier-Smith T. 2003. The root of the eukaryote tree pinpointed. Curr Biol 13: R665-R666.

Steenkamp ET, Wright J, Baldauf SL. 2006. The protistan origins of animals and fungi. Mol Biol Evol 23: 93-106.

Stiller JW. 2011. Experimental design and statistical rigor in phylogenomics of horizontal and endosymbiotic gene transfer. BMC Evol Biol 11: 259.

Takishita K, Kolisko M, Komatsuzaki H, Yabuki A, Inagaki Y, Cepicka I, Smejkalová P, Silberman JD, Hashimoto T, Roger AJ, et al. 2012. Multigene phylogenies of diverse carpediemonas-like organisms identify the closest relatives of "amitochondriate" diplomonads and retortamonads. Protist 163: 344-355.

Tovar J, Fischer A, Clark CG. 1999. The mitosome, a novel organelle related to mitochondria in the amitochondrial parasite Entamoeba histolytica. Mol Microbiol 32: 10131021.

Tovar J, León-Avila G, Sánchez LB, Sutak R, Tachezy J, van der Giezen M, Hernández M, Müller M, Lucocq JM. 2003. Mitochondrial remnant organelles of Giardia function in iron-sulphur protein maturation. Nature 426: $172-176$.

Van de Peer Y, Van der Auwera G, De Wachter R. 1996. The evolution of stramenopiles and alveolates as derived by "substitution rate calibration" of small ribosomal subunit RNA. J Mol Biol 42: 201-210.

Wainright PO, Hinkle G, Sogin ML, Stickel SK. 1993. Monophyletic origins of the metazoa: An evolutionary link with fungi. Science 260: 340-342.

Whittaker H. 1969. New concepts of kingdoms of organisms. Science 163: 150-160. 
The Tree of Eukaryotes

Wideman JG, Gawryluk RM, Gray MW, Dacks JB. 2013. The ancient and widespread nature of the ER-mitochondria encounter structure. Mol Biol Evol 30: 2044-2049.

Williams BA, Hirt RP, Lucocq JM, Embley TM. 2002. A mitochondrial remnant in the microsporidian Trachipleistophora hominis. Nature 418: 865-869.

Williams TA, Foster PG, Nye TM, Cox CJ, Embley TM. 2012. A congruent phylogenomic signal places eukaryotes within the Archaea. Proc R Soc Lond B Biol Sci 279: 4870-4879.

Woese CR, Kandler O, Wheelis ML. 1990. Towards a natural system of organisms: Proposal for the domains Archaea, Bacteria, and Eucarya. Proc Natl Acad Sci 87: 4576-4579.

Yabuki A, Inagaki Y, Ishida K-I. 2010. Palpitomonas bilix gen. et sp. nov.: A novel deep-branching heterotroph possibly related to Archaeplastida or Hacrobia. Protist 161: $523-538$.
Yamamoto A, Hashimoto T, Asaga E, Hasegawa M, Goto N. 1997. Phylogenetic position of the mitochondrion-lacking protozoan Trichomonas tenax, based on amino acid sequences of elongation factors $1 \alpha$ and 2. J Mol Evol 44: 98-105.

Yoon HS, Hackett JD, Pinto G, Bhattacharya D. 2002. The single, ancient origin of chromist plastids. Proc Natl Acad Sci 99: 15507-15512.

Yoon HS, Price DC, Stepanauskas R, Rajah VD, Sieracki ME, Wilson WH, Yang EC, Duffy S, Bhattacharya D. 2011. Single-cell genomics reveals organismal interactions in uncultivated marine protists. Science 332: 714717.

Zhao S, Burki F, Brate J, Keeling PJ, Klaveness D, ShalchianTabrizi K. 2012. Collodictyon-An ancient lineage in the tree of eukaryotes. Mol Biol Evol 29: 1557-1568. 


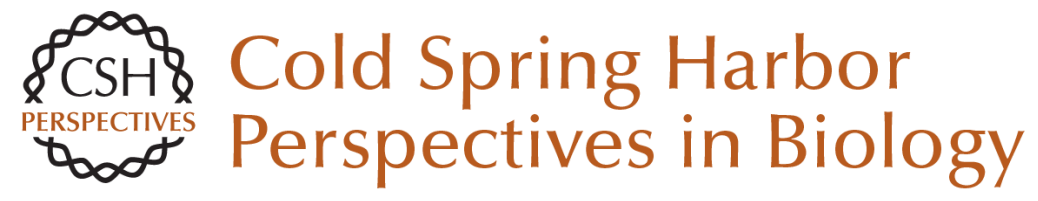

\section{The Eukaryotic Tree of Life from a Global Phylogenomic Perspective}

Fabien Burki

Cold Spring Harb Perspect Biol 2014; doi: 10.1101/cshperspect.a016147

Subject Collection The Origin and Evolution of Eukaryotes

The Persistent Contributions of RNA to Eukaryotic Gen(om)e Architecture and Cellular Function Jürgen Brosius

Green Algae and the Origins of Multicellularity in the Plant Kingdom James G. Umen

The Archaeal Legacy of Eukaryotes: A

Phylogenomic Perspective

Lionel Guy, Jimmy H. Saw and Thijs J.G. Ettema

Origin and Evolution of the Self-Organizing Cytoskeleton in the Network of Eukaryotic Organelles Gáspár Jékely

On the Age of Eukaryotes: Evaluating Evidence from Fossils and Molecular Clocks Laura Eme, Susan C. Sharpe, Matthew W. Brown, et al.

Origin of Spliceosomal Introns and Alternative Splicing Manuel Irimia and Scott William Roy

Protein and DNA Modifications: Evolutionary Imprints of Bacterial Biochemical Diversification and Geochemistry on the Provenance of Eukaryotic Epigenetics

L. Aravind, A. Maxwell Burroughs, Dapeng Zhang, et al.
Eukaryotic Origins: How and When Was the Mitochondrion Acquired?

Anthony M. Poole and Simonetta Gribaldo

Bacterial Influences on Animal Origins Rosanna A. Alegado and Nicole King

Missing Pieces of an Ancient Puzzle: Evolution of the Eukaryotic Membrane-Trafficking System Alexander Schlacht, Emily K. Herman, Mary J. Klute, et al.

The Neomuran Revolution and Phagotrophic Origin of Eukaryotes and Cilia in the Light of Intracellular Coevolution and a Revised Tree of Life

Thomas Cavalier-Smith

Protein Targeting and Transport as a Necessary

Consequence of Increased Cellular Complexity Maik S. Sommer and Enrico Schleiff

How Natural a Kind Is "Eukaryote?" W. Ford Doolittle

What Was the Real Contribution of Endosymbionts to the Eukaryotic Nucleus? Insights from Photosynthetic Eukaryotes David Moreira and Philippe Deschamps

For additional articles in this collection, see http://cshperspectives.cshlp.org/cgi/collection/

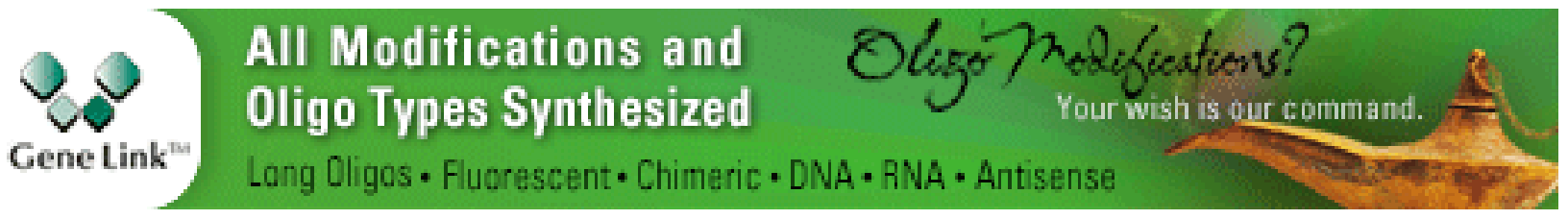


The Eukaryotic Tree of Life from a Global Phylogenomic Perspective Fabien Burki
Bioenergetic Constraints on the Evolution of Complex Life

Nick Lane

For additional articles in this collection, see http://cshperspectives.cshlp.org/cgi/collection/

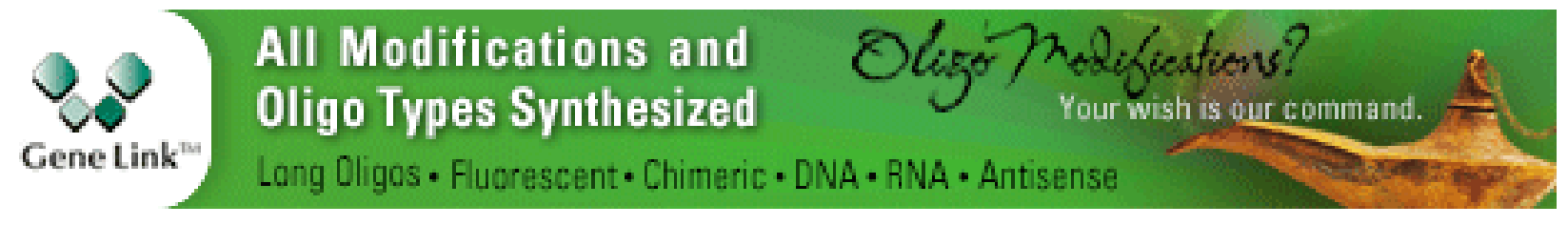

Copyright @ 2014 Cold Spring Harbor Laboratory Press; all rights reserved 